\title{
PENGOLAHAN HASIL PERIKANAN AIR TAWAR DI KELURAHAN PAHANDUT SEBERANG KECAMATAN PAHANDUT KOTA PALANGKA RAYA
}

\author{
Muhamad Noor Yasin ${ }^{1}$, Firlianty ${ }^{2}$, Anang Najamuddin ${ }^{3}$ \\ 1,2,3 Jurusan Perikanan, Universitas Palangka Raya \\ Jalan Yos Sudarso, Kalimantan Tengah \\ ${ }^{2} \mathrm{e}$-mail: firlianty80@gmail.com
}

\begin{abstract}
Abstrak
Kelurahan Pahandut Seberang adalah salah satu kelurahan di wilayah Kecamatan Pahandut Kota Palangkaraya, kelurahan tersebut merupakan salah satu kelurahan yang dipromosikan sebagai tempat sentra kuliner di Kota Palangkaraya. Ikan toman dan ikan patin di Kelurahan ini merupakan ikan yang dipelihara masyarakat pada kolam keramba dan selama ini merupakan sumber penghasilan bagi masyarakat, biasanya ikan ini hanya dijual dalam bentuk ikan segar saja, sehingga penting untuk dilaksanakan pelatihan diversifikasi pengolahan hasil perikanan dari ikan tersebut dalam bentuk olahan nugget, kaki naga dan ekado. Metode dari pelaksanaan kegiatan ini adalah dengan penyuluhan dan pelatihan praktek secara langsung cara pembuatan olahan nugget, kaki naga dan ekado tersebut. Pengolahan hasil perikanan dalam berbagai bentuk olahan ini diharapkan dapat meningkatan nilai gizi dan nilai ekonomi dari ikan yang terdapat di sekitar masyarakat kelurahan Pahandut Seberang.
\end{abstract}

Kata kunci: ikan air tawar, nugget, ekado, kaki naga, pengolahan ikan

\begin{abstract}
Pahandut Seberang is one of the villages in Pahandut district, Palangkaraya city, that is promoted as culinary center. Toman snakehead and Pangasius catfish are the fish species cultured in the fish cage and have become the income source of the local communities. The fish are usually sold in fresh, so that it is important to have training on fish processing to produce fish products, such as nugget, dragon feet, and ecado. This activity was done through socialization and direct practice on how to make the products. The fish processing in these different products is expected to be able to increase nutrition and economic values of the fish resources around the village.
\end{abstract}

Keywords: freshwater fish, Nugget, Ekado, Kaki Naga, fisheries processing

\section{PENDAHULUAN}

Potensi lestari perikanan laut Indonesia diperkirakan sebesar 6,4 juta ton per tahun yang tersebar di perairan wilayah Indonesia dan ZEE (Zona Ekonomi Ekslusif) dengan jumlah tangkapan yang diperbolehkan sebesar 5,12 juta ton pertahun atau sekitar 80 persen dari potensi lestari. Potensi sumberdaya perikanan yang dimiliki Indonesia tersebut dan produksi yang dihasilkannya menunjukkan bahwa perikanan memiliki potensi yang baik untuk kontribusi di dalam pemenuhan gizi masyarakat, khususnya protein hewani, disamping kontribusinya dalam pertumbuhan perekonomian Indonesia (Hendrawati \& Zidni, 2017). 
Kalimantan Tengah memiliki potensi hasil perikanan yang sangat melimpah terutama hasil perikanan air tawar, tetapi permasalahan pada saat ini penguasaan pengolahan akan diversifikasi hasil perikanan tersebut masih sangat terbatas. Sehingga sasaran pengembangan industri perikanan nasional berbasis sumber daya perairan sulit dicapai, apabila sumber daya manusia yang kualitasnya masih rendah. Persoalan ini akan menjadi serius jika tidak ditangani, karena dapat menyebabkan ketergantungan yang sangat tinggi terhadap impor IPTEKS dari negara-negara maju. Salah satu kajian IPTEKS di bidang perikanan adalah pembangunan sektor perikanan selama ini dilaksanakan di Provinsi Kalimantan Tengah hanya untuk meningkatkan perekonomian masyarakat tidak berorentasi terhadap pengelolaan dan pemanfaatan sumberdaya perairan yang ramah lingkungan. Dalam rangka mengantisipasi tantangan yang akan datang untuk mencapai tujuan yang diinginkan, maka secara terus menerus sektor perikanan mengembangkan peluang dan inovasi baru sesuai dengan tuntutan perubahan. Untuk mencapai tuntutan perubahan tersebut harus disusun dalam tahapan yang terencana, konsisten dan berkelanjutan, sehingga akuntabilitas kinerja yang berorientasi pada pencapaian hasil atau manfaat.

Usaha untuk meningkatkan konsumsi ikan masyarakat telah banyak dilakukan, antara lain dengan mengenalkan berbagai macam produk olahan ikan. Pada umumnya produk tersebut kurang diminati karena penampilannya kurang menarik dan cita rasa khas sering kurang disukai masyarakat. Produk olahan dari ikan mempunyai ciri khas yang amis dan rasa yang mencolok sehingga ada sebagian orang yang kurang berminat karena merasa kurang nyaman dengan aroma amis ikan tersebut. Nugget, ekado dan kaki naga yang beredar dipasaran hanya bertujuan untuk memenuhi permintaan pasar yang tinggi tanpa memperhatikan nilai gizi dan kandungan yang terdapat didalamnya. Adanya diversifikasi produk olahan ikan dapat membantu meningkatkan nilai gizi produk Nugget, ekado dan kaki naga dengan penambahan daging ikan air tawar yang didalamnya terkandung zat yang bernama albumin yang memiliki berbagai fungsi yang baik bagi kesehatan (Firlianty, et al., 2013). Daging ikan air tawar masih sedikit yang mengembangkannya sebagai produk diversifikasi produk perikanan 
dan kurang diminati karena bau yang menyengat, rasa yang kurang enak dan bentuk yang tidak menarik. Salah satu cara untuk meningkatkan potensi produk olahan ikan air tawar adalah dengan membuat produk Nugget, ekado dan kaki naga yang berbahan dasar daging ikan air tawar dalam pelaksanaan kegiatan ini dengan menggunakan daging ikan toman (Channa micropeltes) dan ikan patin (Pangasius sp). Ikan banyak mengandung omega 3 dan omega 6 yang sangat diperlukan untuk perkembangan otak ( Rinjani, T dkk, 2018 ).

Kegiatan pengabdian pada masyarakat dengan memberikan pelatihan dan demonstrasi produk nugget, ekado dan kaki naga ikan air tawar, ini merupakan sebagai usaha ibu-ibu rumah tangga di Kecamatan Pahandut RT 05 dalam mengembangkan produk olahan ikan air tawar.

Kegiatan ini merupakan pembinaan langsung terhadap mitra ibu-ibu rumah tangga di Kecamatan Pahandut melalui penyuluhan, diskusi, bimbingan serta praktek langsung tentang olahan dari ikan air tawar. Kegiatan ini diharapkan dapat meningkatkan pengetahuan dan keterampilan ibu-ibu rumah tangga dalam berusaha mengolah potensi perikanan khususnya ikan lokal secara kontinyu yang tentunya mempunyai pengaruh besar terhadap perekonomian/penghasilan dan kesejahteraan ibu-ibu rumah tangga itu sendiri sehingga bisa menjadi salah satu ciri khas olahan Kalimantan Tengah. Khusus pada saat pandemik seperti sekarang ini tentunya pengolahan produk dari hasil perikanan akan memberikan manfaat yang sangat besar bagi peningkatan gizi masyarakat. Permasalahan yang dihadapi mitra adalah (1) selama ini mitra belum mengetahui variasi tentang teknologi hasil perikanan karena terbatasnya pengetahuan dan informasi yang diterima serta keterampilan yang dimiliki, (2) mitra juga belum pernah mendapatkan pelatihan dan demonstrasi tentang pembuatan Nugget, eccado dan kaki naga dari ikan air tawar dalam hal ini ikan family Channidae dan Pangasius Sp. 


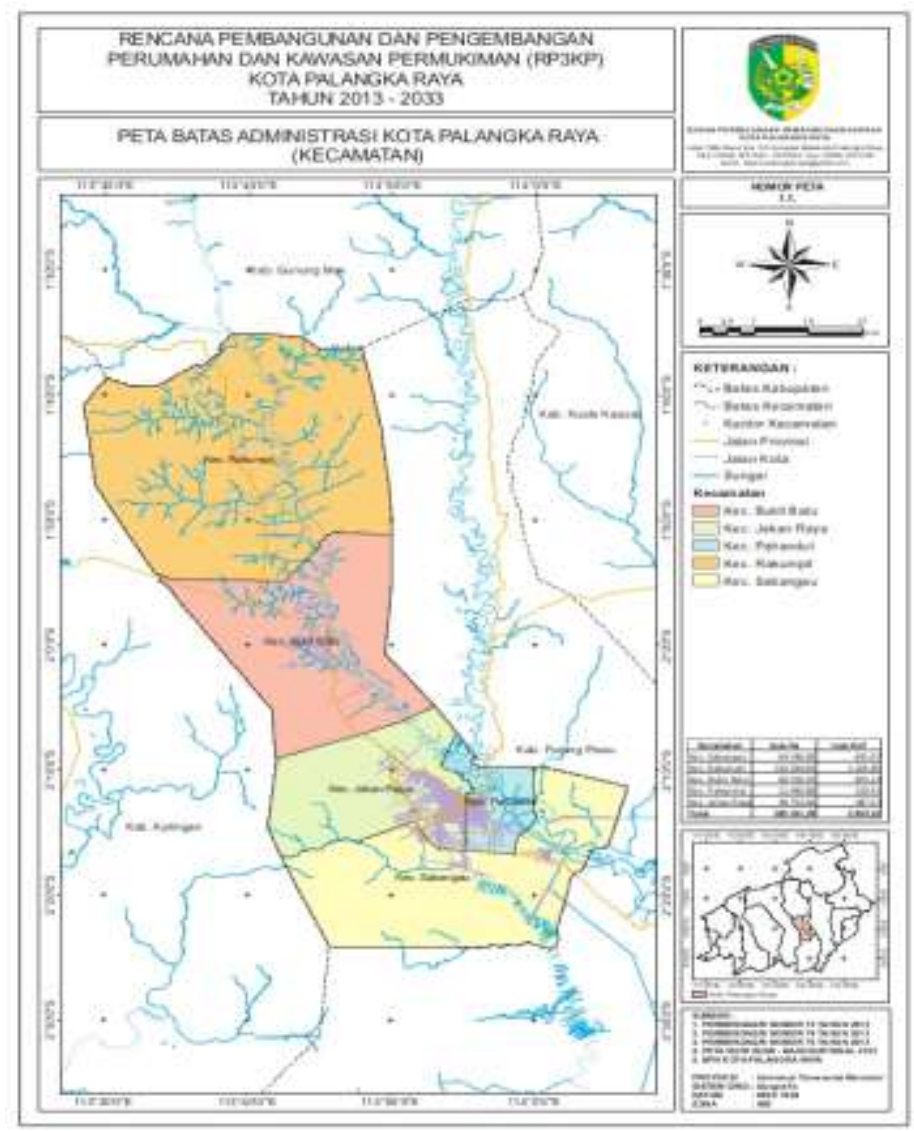

Gambar 1. Peta Lokasi Kegiatan Pengabdian

\section{METODE}

Kegiatan pengabdian ini dilaksanakan dalam dua kegiatan yaitu kegiatan sosialisasi dan pelatihan secara langsung dalam pembuatan nugget, ekado dan kaki naga ikan air tawar. Pelaksanaan kegiatan 7 Maret 2020 lokasi kegiatan di Kecamatan Pahandut kelurahan Pahandut seberang RT 05/ Rw II. Peserta dari kegiatan ini adalah ibu-ibu dan remaja putri.

Metode pelaksanaan kegiatan pengabdian ini dengan penyuluhan dan pelatihan langsung yang dilakukan bersama-sama dengan ibu-ibu yang menjadi peserta mengolah nugget, ekado dan kaki naga dari ikan lokal air tawar yang dengan mudah didapatkan seputar kota Palangkaraya. Dalam demonstrasi ini juga diberikan kesempatan tanya jawab dengan peserta.

Gambaran IPTEKS yang akan ditransfer kepada masyarakat (ibu-ibu RT dan remaja putri) adalah berupa: (a) meningkatnya ketrampilan masyarakat (ibu- 
ibu RT dan remaja putri) dalam mengolah hasil perikanan terutama Nugget, ekado dan kaki naga dari ikan lokal air tawar, (b) meningkatnya kreativitas dan innovasi masyarakat (ibu-ibu RT dan remaja putri) dalam menciptakan menu dari produk perikanan berupa Nugget, ekado dan kaki naga dari ikan air tawar, (c) melatih masyarakat (ibu-ibu RT dan remaja putri) untuk dapat menciptakan menu olahan produk ikan lokal. Pada akhir kegiatan dilaksanakan evaluasi bagi ibu-ibu dan remaja putri yang mengikuti kegiatan untuk mengetahui pemahaman mereka tentang kegiatan yang sudah dilaksanakan, serta mengetahui keterampilan yang mereka dapatkan dari pelatihan yang sudah terlaksana.

\section{HASIL DAN PEMBAHASAN}

Kelurahan Pahandut Seberang merupakan kelurahan yang dicanangkan menjadi kelurahan sentra kuliner untuk Kota Palangkaraya, sehingga dengan adanya pencanangan tersebut perlu adanya pelatihan diversifikasi produk hasil perikanan di daerah tersebut agar kuliner dari produk perikanan menjadi salah satu produk favorit yang dapat dinikmati masyarakat sekitar dan pengunjung yang akan datang kesana. Pelatihan dan demonstrasi pembuatan ekado, kaki naga dan nugget ikan dengan memanfaatkan daging ikan Toman dan ikan patin yang memiliki kandungan gizi yang tinggi. Pelatihan secara langsung dengan melibatkan peserta dapat menjadi pelatihan yang tepat sasaran karena peserta nantinya dapat mudah mempraktekan pengolahan produk tersebut sendiri tanpa adanya pendampingan. Metode kegiatan berupa penyuluhan dan pembuatan produk. Pengabdian masyarakat program kemitraan wilayah ini dimaksudkan agar keterampilan dari masyarakat itu meningkat dengan adanya pelatihan ini, salah satu tujuan dari diversifikasi pengolahan produk perikanan ini adalah untuk meningkatkan gizi bagi masyarakat terutama pada masa pandemi covid 19 ini dimana ikan merupakan sumber utama kandungan protein tinggi yang diperlukan oleh tubuh. Masyarakat di kelurahan Pahandut Seberang dapat menjadi ikon keberhasilan dari gemar makan ikan yang sedang gencar dicanangkan pemerintah saat ini. Menciptakan image dari ikan adalah produk yang murah meriah dan bergizi tinggi tidaklah mudah karena tidak semua orang menyukai produk 
perikanan yang memiliki khas bau amis. Keberhasilan dari pelaksanaan kegiatan yang dilaksanakan adalah dengan terlihatnya peserta menjadi terampil dalam pengolahan produk tanpa ada kesulitan yang berarti. Pada Pelaksanaan kegiatan pelatihan produk yang pertama dibuat adalah produk ekado ikan, Ekado merupakan salah satu jenis olahan fish jelly produk dengan menggunakan kulit pangsit yang berfungsi sebagai pembungkus memberikan rasa yang khas. Produk ini dikonsumsi dengan cara digoreng dan siap dihidangkan (DKP, 2008). Gamabr 2 menyajikan pembuatan ekado dari ikan yang dilaksanakan.
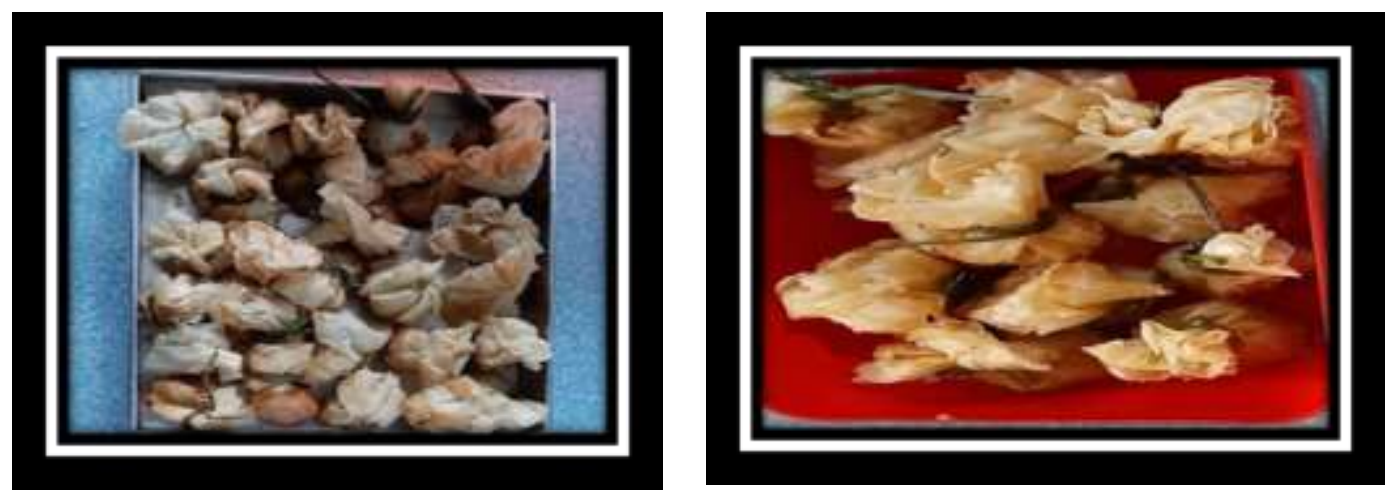

Gambar 2. Dokumentasi Kegiatan Pembuatan Ekado

Produk berikutnya yang dibuat adalah kaki naga merupakan makanan hasil perikanan favorit semua kalangan masyarakat di Jakarta. Mengingat masyarakat Jakarta umumnya menyukai makanan yang praktis dan cepat saji. Keberagaman produk hasil olahan perikanan menjadikan konsumsi ikan di masyarakat menjadi semakin meningkat. Proses produksi pembuatan kaki naga ikan dimulai dari penerimaan bahan baku berupa fillet ikan yang masih segar, kemudian dilanjutkan dengan proses penggilingan fillet ikan hingga berbentuk pasta, pengadukan adonan dengan penambahan bahan baku lainnya, pemasakan, pencetakan menggunakan tangan dan sendok atau garpu, penggorengan secara deep frying, penirisan di meja penirisan, batter, breading, ditusuk dengan sumpit, pengemasan, dan pembekuan. Produk kaki dimanfaatkan sebagai makanan penunjang atau pelengkap dari makanan pokok. Kaki naga yang praktis serta cepat disajikan dan kaya akan kandungan gizi menyebabkan makanan ini banyak digemari baik dari anak kecil hingga orang dewasa. Selain itu produk ini rasanya gurih sehingga 
dapat membantu menambah nafsu makan, dengan bentuk yang menarik membuat produk ini menarik konsumen untuk membelinya. Pemilihan usaha kaki naga dapat dilakukan dari bahan baku utama berupa fillet ikan patin sangat mudah didapatkan.
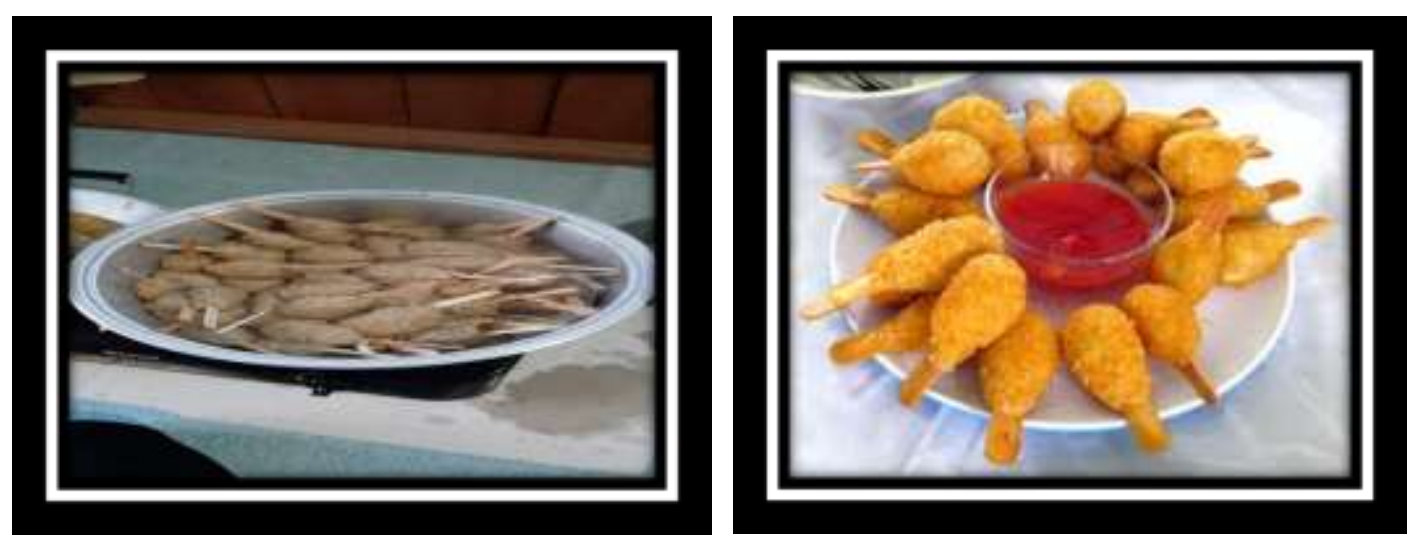

\section{Gambar 3. Dokumentasi Pembuatan Kaki Naga}

Kemudian produk yang ketiga pada kegiatan pengabdian ini adalah nugget ikan. Nugget merupakan salah satu bentuk produk makanan beku siap saji, yaitu produk yang telah mengalami pemanasan sampai setengah matang (precooked), kemudian dibekukan. Produk beku siap saji ini hanya memerlukan waktu penggorengan selama 1 menit pada suhu $150^{\circ} \mathrm{C}$ (Ginting, 2015). Nugget ikan merupakan olahan produk baru, pembuatan nugget dari ikan memerlukan bahanbahan tambahan yang berperan sebagai bahan pengisi dan bahan pengikat disamping bumbu dan rempah-rempah, bahan pengisi yang biasa digunakan adalah tepung. Syarbini (2013) menyatakan bahwa tepung terigu adalah hasil dari penggilingan biji gandum. Umumnya tepung terigu biasa digunakan untuk membuat aneka makanan seperti kue dan roti. Tepung terigu mengandung gluten yang dapat membuat adonan makanan menjadi tipis danelastis. Nugget dengan bahan baku ikan masih belum banyak dijumpai di pasaran. Pengembangan ikan sebagai bahan baku nugget sangat penting, karena ikan mengandung protein yang tidak kalah tinggi dengan ayam terutama untuk membantu meningkatkan nilai ekonomis produk. Gambar 4 menyajikan produk nugget ikan yang diolah bersama ibu-ibu dan remaja putri RT 05. 

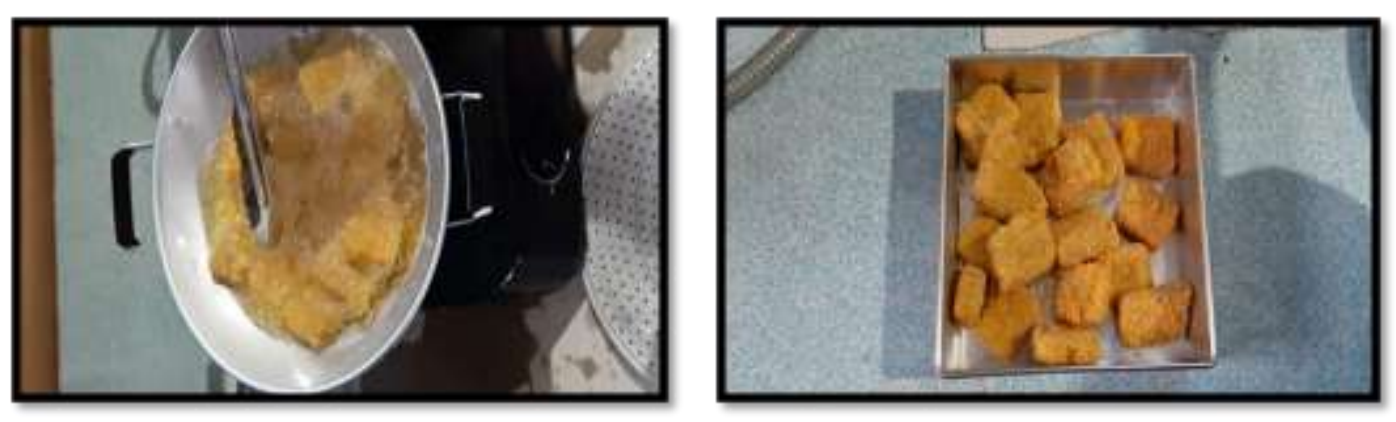

Gambar 4. Dokumentasi Pembuatan Nugget

Hasil dari pelatihan ini, sebagian besar peserta sangat merasakan manfaatnya dan memberikan keterampilan untuk diversifikasi mengolah produk hasil perikanan, selanjutnya berdasarkan saran dan masukan peserta, perlu diadakan kegiatan lanjutan sejenis, agar peserta dapat mengevaluasi hasil yang telah dijalankan dan meningkatkan kualitas karya dengan adanya kesempatan untuk konsultasi dengan perguruan tinggi pelaksana pengabdian dan mendapat pelatihan dengan tingkat kompetensi yang lebih tinggi. Peserta menghendaki kegiatan pendampingan ini dapat menginisiasi pembentukan Kelompok Wanita Pengolah Hasil Perikanan sebagai tindak lanjut hasil pelatihan terutama diversifikasi olahan daging ikan menjadi produk pangan yang bernilai ekonomi, baik untuk memenuhi kebutuhan rumah tangga sendiri maupun dijual sebagai tambahan penghasilan, serta mampu meningkatkan kesehatan dan taraf perekonomian masyarakat.

\section{SIMPULAN}

Keterampilan cara mengolah hasil perikanan terutama dari ikan yang selama ini menjadi pendapatan bagi masyarakat dikelurahan Pahandut Seberang dapat menjadi alternatif penghasilan tambahan bagi ibu-ibu dan remaja putri di kelurahan Pahandut Seberang. Manfaat yang sangat berguna bagi masyarakat dalam rangka meningkatkan gizi dan kesejahteraan ekonomi masyarakat, dan dengan adanya diversifikasi dari olahan ikan air tawar ini juga akan memperkenalkan Kota Palangkaraya sebagai kota yang memiliki sumberdaya 
hasil perikanan terutama perikanan air tawar yang cukup melimpah dan bermaanfaat untuk kesehatan masyarakat.

\section{DAFTAR PUSTAKA}

Firlianty, Suprayitno, E., Nursyam, H., Hardoko, \& Mustafa, A. (2013). Chemical composition and amino acid profile of channidae collected from central Kalimantan, Indonesia.

Ginting. (2015). Penggunaan bahan pengisi pada nugget. Jurnal Agribisnis.

Hendrawati, S., \& Zidni, I. (2017). Gambaran konsumsi ikan pada keluarga dan anak paud rw 07 desa cipacing. Jurnal Pengabdian Kepada Masyarakat, 1(2), 101-106.

Rinjani, T., Hasibuan, E, Basma., dan Susanti, I, A. (2018). Pemberdayaan ibu rumah tangga melalui penyuluhan tentang ikan dan udang yang layak konsumsi untuk memenuhi gizi keluarga (studi kasus di rw 03 desa cipacing kecamatan jatinangor kabupaten Sumedang). Jurnal Pengabdian Kepada Masyarakat UNPAD, 2(2), 108112. 